\title{
Profile of the appendectomies performed in the Brazilian Public Health System
}

\section{Perfil das apendicectomias realizadas no Sistema Público de Saúde do Brasil}

\author{
Fernanda dos Santos ${ }^{1}$; Gabriel Flamarim Cavasana ${ }^{1}$; Tercio de Campos, TCBC-SP¹.
}

\author{
A B S T R A C T
}

\begin{abstract}
Objective: to analyze the profile of appendectomies performed in the Brazilian Public Health System (SUS) and to compare the laparoscopic and laparotomic techniques of appendectomy. Methods: This work used information from DataSus from 2008 to 2014 (http://datasus.saude. gov.br). We compared the data of patients submitted to laparotomic appendectomy with those submitted to laparoscopic one. Results: when comparing the total growth of appendectomies, the laparoscopic route increased $279.7 \%$, while the increase in laparotomic surgery was $25 \%(p<0.001)$ in the study period. With regard to medical and hospital costs, laparoscopic appendectomy accounted for only $2.6 \%$ of the total expenditure on appendectomies performed by the Unified Health System (SUS) hospitals, with an average cost 7.6\% lower than that of laparotomy procedures, but without statistical significance. The mortality rate was 57.1\% lower in the laparoscopic approach when compared with laparotomy. Conclusion: there has been a significant increase in the laparoscopic route in the treatment of appendicitis, but the method is still rarely used in SUS patients. The costs of laparoscopic appendectomy were similar to those observed in laparotomic access.
\end{abstract}

Keywords: Appendicitis. Laparoscopy. Appendectomy. Health Expenditures.

\section{INTRODUCTION}

cute appendicitis is the most common cause of acute
abdomen in the child, adolescent, and young adult, with a peak incidence in the 2 nd and 3rd decades of life'. In 1894, McBurney established the surgical treatment as the best way to handle acute appendicitis, and in 1983, Kurt Semm, a German gynecologist, performed the first laparoscopic appendectomy². Despite the description of the success of the clinical treatment of acute appendicitis by some authors, appendectomy, either laparotomic or laparoscopic, continues to be the treatment of choice ${ }^{3,4}$. Technical variations of these access routes are described in the literature, depending on the stage of the disease and its evolution, the patient's clinical situation, the surgeon's experience, aesthetic aspects, the patient's anatomy and the availability of local resources.

The classic laparotomic approach is through the McBurney ${ }^{5}$ incision. The laparoscopic approach, usually performed through three ports, is a minimally invasive method and associated with a lower incidence of postoperative pain ${ }^{6,7}$.

It is of extreme relevance that studies are made to compare the techniques and encourage the training of professionals with the modern surgical methods, when these are superior. Santos Júnior and Guimarães emphasize the evidence-based surgical practice on the importance of research with high scientific background 8 .

The objective of this study is to analyze the profile of appendectomies performed at SUS and to compare the laparoscopic and laparotomic techniques.

\section{METHODS}

This work used DataSus information from 2008 to 2014 (http://datasus.saude.gov.br). To obtain the data, the we used the Portuguese terms for "appendectomy" and "videolaparoscopic appendectomy". The analyzed variables were: total number of hospitalizations, total hospitalization costs, mean hospitalization costs, mean length of stay and mortality rate. We compared the data of patients submitted to laparotomic appendectomy with those submitted to laparoscopic one. We placed the data in an Excel spreadsheet and exposed it in charts. For statistical analysis, w used the Chi-square test, considering $p<0.05$ as significant. The work was approved by the Ethics and Research Committee of the

1 - Anhembi Morumbi University, Sao Paulo, Sao Paulo State, Brazil 


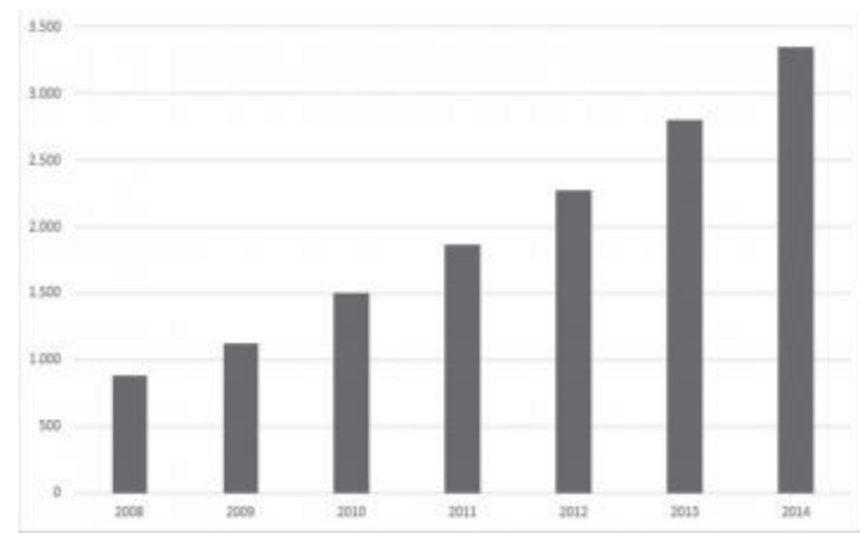

Figure 1. Evolution of the number of laparoscopic appendectomies between 2008 and 2014.

Anhembi Morumbi University of São Paulo, approval number: CAAE 57409016800005492.

\section{RESULTS}

The total number of appendectomies was 684,278 in this period, with a mean of 97,754 per year. Of this, 2\% were laparoscopic, representing 13,801 procedures in absolute values. When comparing the total growth between the years 2008 and 2014, the laparoscopic route increased by $279.7 \%$, while the increase in appendectomy by laparotomy was 25\% ( $p$ $<0.001$ ) (Figures 1 and 2).

The number of laparoscopic surgeries in the South Region of the country corresponded to $57 \%$ of the total number of those performed in Brazil, followed by the Southeast Region, with $29 \%$. The laparotomic route was used in these regions in $21 \%$ and $41 \%$ of the total number of surgeries, respectively (Figure 3 ).

The total cost of surgeries performed, counting medical and hospital expenses, was $R \$ 318,207,595.08$. Of this total, surgeries with laparoscopic access accounted for $2.6 \%$, with an expenditure of $R \$ 8,137,417.59$, while for the laparotomic procedures the total expenses were $\mathrm{R} \$ 310,070,177.49$. The average cost of the laparoscopic surgeries was $R \$ 500.06,7.6 \%$ less than that of conventional surgeries, which had an average cost of $R \$ 537.88$, however without a statistically significant difference.

The mean length of hospital stay with laparotomies was 3.8 days, while with laparoscopy, 3.6 days, with no statistical difference.

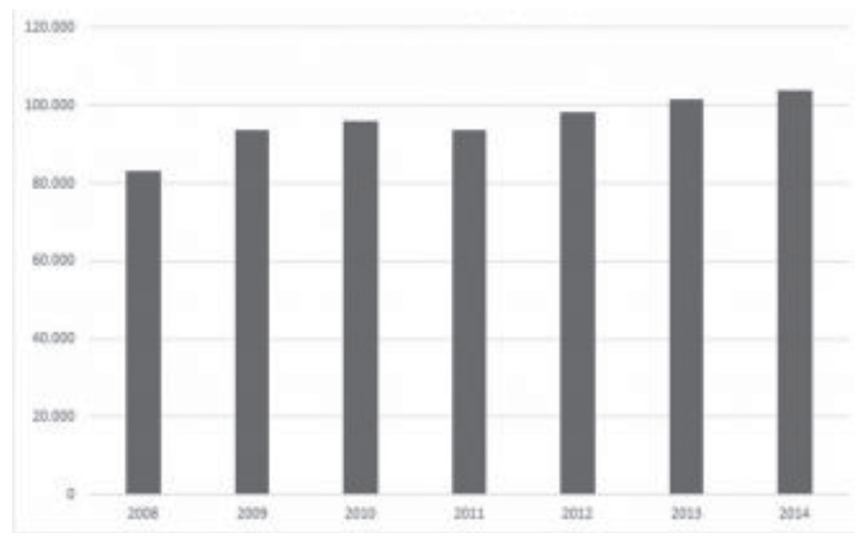

Figure 2. Evolution of the number of appendectomies by laparotomy between 2008 and 2014.

The mortality rate was $57.1 \%$ lower in the laparoscopic route when compared with the laparotomic one during the seven years of analysis $(0.12 \% \times 0.28 \%)$, a statistically significant difference (Figure 4).

\section{DISCUSSION}

Acute appendicitis is the most common intraabdominal pathological condition requiring surgical intervention. Thus, it is extremely relevant that reference services have surgeons trained to perform the surgical technique that brings greater benefits to the patient and that can deal with eventual complications of the surgical procedure ${ }^{9}$. Most appendectomies in SUS patients are still performed through laparotomy. There is no consensus in the literature regarding the benefit of the laparoscopic route in relation to the laparotomic one, especially when regarding costs and mortality. Although the laparoscopic approach requires specific instruments and greater technical qualification, our study demonstrated that there was no increase in hospitalization costs when using the laparoscopic route. However, the need for specific equipment associated with the need for surgeon training justifies the lesser use of the laparoscopic technique in SUS. There are a number of surgeons who still do not master the laparoscopic technique, and the material needed to perform the procedure is not widely available in hospitals attending SUS patients. But considering that only $2 \%$ of the surgical treatments of acute appendicitis were performed laparoscopically in the period studied and that this has a $7.6 \%$ lower cost in relation to the 


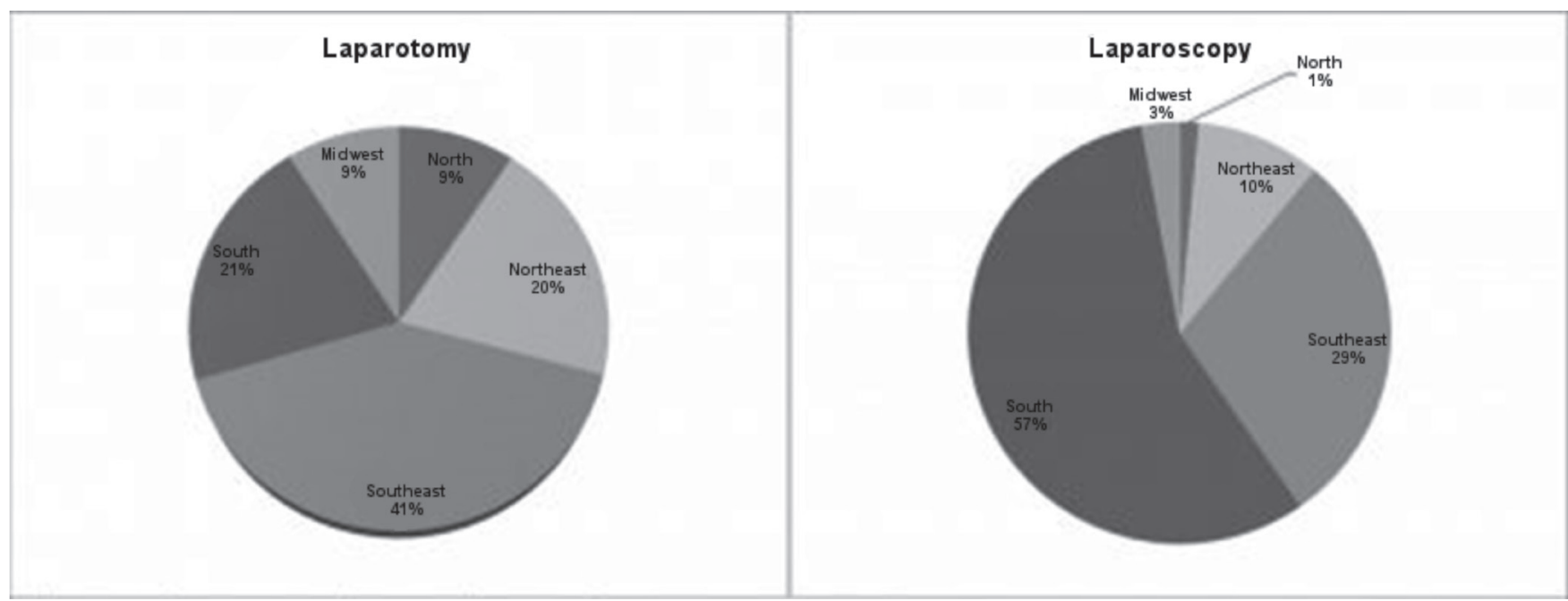

Figure 3. Distribution of laparoscopic and laparotomic surgeries in Brazil's five regions between 2008 and 2014.

laparotomic route, taking into account the figures raised in this work, if all surgeries had been performed laparoscopically, there would be a reduction in the total cost of approximately $\mathrm{R} \$ 23$ million.

In addition, laparoscopic surgery is a less invasive method with less repercussions, both systemic and in the abdominal wall ${ }^{10,11}$. In this study with SUS patients, there was a $57.1 \%$ reduction in the mortality rate in relation to laparotomy. It should be considered, however, that there was no comparison between the access routes by gravity of the cases and. It is possibly that more complicated patients had the initial approach by laparotomy.

Contrary to what we observed in our study, most patients with acute appendicitis operated in private hospitals are preferably submitted to laparoscopic surgery ${ }^{12}$. This reality, however, is already beginning to change, since we observed a significant increase in the number of laparoscopic procedures in the Study period, well above the increase in open appendectomies. The Southern Region of Brazil was where the largest number of laparoscopic surgeries were performed, possibly due to the easier access to equipment and to the surgeons training.

Early recovery, less need for analgesics, earlier return to daily activities and better aesthetic results are major factors in favor of laparoscopic appendectomy 11,13,14. Our results, however, did not show a significant difference in patients' mean hospital stay. Sozutek et al. ${ }^{15}$ conducted prospective, randomized study and found a significant difference in length of hospital stay, in which the laparoscopic route showed a reduction of 0.8 days in relation to the laparotomy ( $p$ <.05). In our country, this fact could contribute to increase the availability of beds in SUS hospitals.

The tendency is that laparoscopic surgery becomes the method of choice for appendectomies, as reported by Coccolini et al. ${ }^{16}$ in a recent literature systematic review. The method was superior in cases of obese and female patients ${ }^{1}$, besides facilitating the exploration of the entire abdominal cavity when necessary, allowing differential diagnoses and cleaning of the cavity ${ }^{6}$. In patients with peritoneal adhesions due to previous surgeries, with generalized peritonitis or with previous intra-abdominal inflammatory diseases, laparoscopic surgery may present greater technical difficulty and greater chance of conversion to laparotomy ${ }^{10,12}$.

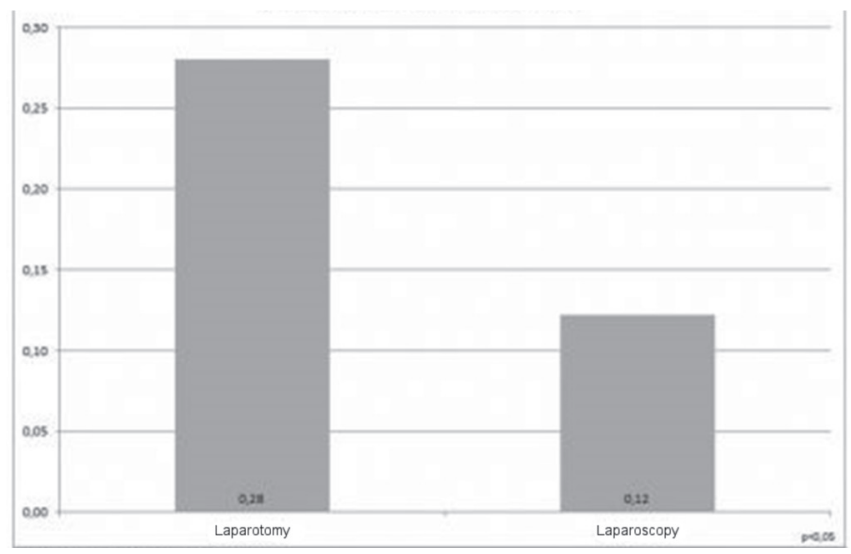

Figure 4. General mortality rate according to the access route. 
This paper presents some limitations. One of these occurs due to the restriction of the information in the DataSus, since this database does not allow to widely evaluate the patients' epidemiological profile. Variables such as gender, ethnicity, age range, comorbidities prior to admission, complications related to the main disease, degree of inflammation of the appendix are also not available in this database. Groups of patients were similar, which could somehow compromise the final analysis. A better development in the database, especially considering clinical and surgical urgencies, can be useful in the planning of strategies for the best service of the population in the emergency services. In addition, it uses data only from patients treated at SUS hospitals, not allowing the analysis of patients operated in private medical services. On the other hand, the series obtained by this database is considerable and the most extensive so far in the country.

Thus, the present study suggests that the laparoscopic route has a growth potential for the treatment of acute appendicitis in Brazil, with the possibility of reducing treatment costs.

\title{
R E S U M O
}

\begin{abstract}
Objetivo: analisar o perfil das apendicectomias realizadas no Sistema de Saúde Pública (SUS) do Brasil e comparar as técnicas de apendicectomia, por via laparoscópica e laparotômica. Método: este trabalho utilizou informações do DataSus de 2008 a 2014 (http:// datasus.saude.gov.br). Foram comparados os dados dos doentes submetidos à apendicectomia laparotômica com aqueles submetidos à apendicectomia laparoscópica. Resultados: ao se comparar o crescimento total das apendicectomias, a via laparoscópica aumentou $279,7 \%$, enquanto o aumento da cirurgia laparotômica foi $25 \%(p<0,001)$ no período do estudo. Com relação aos custos com despesas médicas e hospitalares, a apendicectomia vídeo-laparoscópica representou apenas 2,6\% do gasto total em apendicectomias realizadas por hospitais do Sistema Único de Saúde (SUS) com custo médio 7,6\% inferior ao das cirurgias por via laparotômica, porém sem significância estatística. A taxa de mortalidade foi 57,1\% menor na via laparoscópica quando comparado com a laparotômica. Conclusão: vem havendo um aumento significativo da via laparoscópica no tratamento das apendicites, mas o método ainda é pouco utilizado nos doentes do SUS. Os custos da apendicectomia laparoscópica se mostraram semelhantes aos observados nos acessos laparotômicos.
\end{abstract}

Descritores: Apendicite. Apendicectomia. Laparoscopia. Gastos em Saúde

\section{REFERENCES}

1. Franzon O, Piccoli MC, Neves TT, Volpato MG. Apendicite aguda: análise institucional no manejo peri-operatório. Arq Bras Cir Dig. 2009;22(2):72-5.

2. Semm K. Endoscopic appendectomy. Endoscopy. 1983;15(2):59-64.

3. Malik AA, Bari S. Conservative management of acute appendicitis. J Gastrointest Surg. 2009;13(5):966-70.

4. Santos Júnior JCM, Martins Júnior A; Feres O; Shid RA. Plasträo apendicular: tratamento conservador com apendicectomia eletiva retardada. Rev Col Bras Cir. 1990;17(4):82-5.

5. Goffi FS, Tolosa EMC. Técnica cirúrgica: Bases anatômicas, fisiopatológicas e técnica cirúrgica. 4a ed. São Paulo: Atheneu; 2007.

6. Lima GJS, Silva AL, Leite RFG, Abras GM, Castro EG, Pires LJS. Apendicectomia videoassistida por acesso único transumbilical comparada à via laparoscópica e laparotômica na apendicite aguda. ABCD, arq bras cir dig. 2012;25(1):2-8.
7. Li X, Zhang J, Sang L, Zhang W, Chu Z, Li X, et al. Laparoscopic versus conventional appendectomy--a meta-analysis of randomized controlled trials. BMC Gastroenterol. 2010;10:129.

8. Santos Júnior B; Guimarães CA. Práticas cirúrgicas baseadas em evidências: apendicectomia laparoscópica versus a céu aberto. Rev Col Bras Cir. 2008;35(1):56-60.

9. Liu ZH, Li C, Zhang XW, Kang L, Wang JP. Meta-analysis of the therapeutic effects of antibiotic versus appendicectomy for the treatment of acute appendicitis. Exp Ther Med. 2014;7(5):1181-6.

10. Teixeira N, Basseres $T$, Santos T, Pereira CC, Pinheiro G, Cunha P. A abordagem laparoscópica na apendicite aguda. Rev Port Cir. 2012;(23):15-21.

11. Gomes CA, Nunes TA. Classificação laparoscópica da apendicite aguda: correlação entre graus da doença e as variáveis perioperatórias. Rev Col Bras Cir. 2006;33(5):289-93.

12. Nahas SC, Lourenção JL, Borba MR, Marques CFS, Nahas CSR, Dias AR. Apendicectomia laparoscópi- 
ca: utilizando-a como rotina. Rev bras videocir. 2004;2(3):118-22.

13. Wei B, Qi CL, Chen TF, Zheng ZH, Huang JL, Hu BG, et al. Laparoscopic versus open appendectomy for acute appendicitis: a metaanalysis. Surg Endosc. 2011;25(4):1199-208.

14. Ohtani $H$, Tamamori $Y$, Arimoto $Y$, Nishiguchi $Y$, Maeda K, Hirakawa K. Meta-analysis of the results of randomized controlled trials that compared laparoscopic and open surgery for acute appendicitis. J Gastrointest Surg. 2012;16:1929-39.

15. Sozutek A, Colak T, Dirlik M, Ocal K, Turkmenoglu O, Dag A. A prospective randomized comparison of single-port laparoscopic procedure with open and standard 3-port laparoscopic procedures in the treatment of acute appendicitis. Surg Laparosc En- dosc Percutan Tech. 2013;23(1):74-8.

16. Coccolini F, Tranà C, Sartelli M, Catena F, Di Saverio $S$, Manfredi $R$, et al. Laparoscopic management of intra-abdominal infections: systematic review of the literature. World J Gastrointest Surg. 2015;7(8):160-9.

Received in: 26/09/2016

Accepted for publication: 03/11/2016

Conflict of interest: none.

Source of funding: none.

\section{Mailing address:}

Fernanda dos Santos

E-mail: dast.fernanda@gmail.com gcavasana@hotmail.com 